\title{
PENGGUNAAN NICAS SEBAGAI PENGGANTI ASAM LAKTAT UNTUK MENGEVALUASI KEBERHASILAN RESUSITASI SEPSIS DAN SYOK SEPSIS
}

\author{
Isabella Kusuma Anjelin ${ }^{\star 凶}$, Antonius Freddy ${ }^{*}$, Soeryanto Eko Agung Nugroho*, Nanik Setijowati*
}

\begin{abstract}
Abstrak
Patofisiologi sepsis yang kompleks memberikan banyak tantangan dalam manajemen maupun evaluasi terapinya. Gangguan pada sistem kardiovaskular seperti penurunan tekanan perifer, peningkatan permeabilitas vaskuler, gangguan kontraktilitas, penurunan indeks jantung dan fraksi ejeksi penting diperhatikan dalam manajemen kasus sepsis. Evaluasi kadar asam laktat merupakan salah satu cara untuk mengevaluasi hasil resusitasi pada pasien sepsis dan syok sepsis, tetapi pemeriksaannya memakan waktu, biaya ekstra, dan menimbulkan ketidaknyamanan pada pasien. Penelitian ini bertujuan untuk mengetahui kesesuaian alat NiCAS dalam mengevaluasi perbaikan kondisi pasien sepsis dan syok sepsis dibandingkan dengan asam laktat. Penelitian ini merupakan penelitian observasional analitik dengan pengambilan data primer yang dilakukan di IGD RS. dr. Saiful Anwar (RSSA) Malang mulai Desember 2017 -Desember 2018. Kriteria inklusi meliputi pasien dengan kecurigaan sepsis dan syok sepsis di IGD RSSA Malang dan berusia lebih dari 18 tahun, dan didapatkan 26 pasien yang memenuhi kriteria inklusi. Hasil menunjukkan perubahan kadar asam laktat yang signifikan $(p=0,002)$. Dari semua variabel hemodinamik yang diperiksa dengan NiCAS, perubahan signifikan hanya didapatkan pada total body water $(p=0,006)$. Tidak didapatkan korelasi yang signifikan antara perubahan kadar asam laktat dengan perubahan variabel hemodinamik $(p>0,05)$. Ada kesesuaian antara perubahan kadar asam laktat dengan perubahan variabel hemodinamik $(p>0,05)$ tetapi hanya pada $50-65 \%$ kasus. Terdapat kesesuaian perubahan kadar asam laktat dengan variabel-variabel hemodinamik pada sebagian kasus. Penggunaan alat NiCAS bisa dipertimbangkan untuk monitoring pasien, tetapi belum bisa menggantikan fungsi asam laktat.
\end{abstract}

Kata kunci: hemodinamik, laktat, nicas, sepsis, syok sepsis.

\section{UTILIZATION OF NICAS AS A REPLACEMENT FOR LACTATE LEVELS TO EVALUATE THE RESULT OF RESUSCITATION IN SEPSIS AND SEPTIC SHOCK}

\begin{abstract}
The complex pathophysiology of sepsis creates many challenges in its management and evaluation of therapy. Cardiovascular damages including decreased peripheral resistance, increased vascular permeability, contractility problem, decreased cardiac index and ejection fraction are important concerns in sepsis management. Evaluation of lactate levels is a way to evaluate the results of resuscitation in septic and septic shock patients, but it takes time, adds cost, and causes discomfort to the patients. This study is aimed to evaluate the suitability of NiCAS to evaluate the improvement of the condition of septic and septic shock patients in comparison to lactate levels. This was an analytic observational study with primary data collection conducted in the Emergency Department of Saiful Anwar Hospital (RSSA) Malang from December 2017 - December 2018. Included in the samples were patients with suspected sepsis and septic shock in the ED of RSSA Malang and over 18 years old. In this study, there were 26 patients who met the inclusion criteria. Significant changes in lactate levels were obtained with $p=0.002$. Of all hemodynamic variables examined by NiCAS, significant changes were only found in total body water $(p=$ 0.006). There was no significant correlation between changes in lactate levels with changes in hemodynamic variables $(p>0.05)$. Accuracy was found between changes in lactic acid levels and changes in hemodynamic variables $(p>0.05)$ but only in $50-65 \%$ of cases. There is a similarity of changes in lactate levels compared to hemodynamic variables in some cases. The use of NiCAS can be considered for patient monitoring, but it cannot yet replace the function of lactate levels.
\end{abstract}

Keywords: hemodynamic, lactate, nicas, sepsis, sepsis shock.

* Departemen Emergensi Medisin, Fakultas Kedokteran, Universitas Brawijaya-RS. dr. Saiful Anwar Malang

** Departemen IImu Kesehatan Masyarakat dan Kedokteran Pencegahan, Fakultas Kedokteran,

Universitas Brawijaya

$\bowtie$ E-mail: isabella.anjelin@gmail.com 


\section{Pendahuluan}

Sepsis menyebabkan jutaan kematian di seluruh dunia setiap tahunnya. ${ }^{1}$ Insiden sepsis diperkirakan mencapai 18 juta kasus setiap tahunnya. ${ }^{2}$ Sepsis didefinisikan sebagai disfungsi organ yang mengancam jiwa (life threatening) disebabkan karena disregulasi respons inang terhadap infeksi.3,4 Sepsis dapat menyebabkan pengeluaran biaya yang sangat mahal, baik untuk pemeriksaan penunjang, ataupun biaya pengobatannya. Di IGD (Instalasi Gawat Darurat) RSUD dr. Saiful Anwar (RSSA) Malang pada triwulan I dan II tahun 2015, sepsis menempati urutan ke-9 dari 10 besar penyakit gawat darurat, sedangkan pada triwulan III tahun 2015, menempati urutan ke-7. Sepsis menjadi penyebab kematian terbanyak di RSUD $d r$. Saiful Anwar Malang sepanjang tahun 2015. ${ }^{5}$

Sepsis dapat menyebabkan kerusakan multiorgan. Secara khusus, gangguan pada sistem kardiovaskular seperti penurunan tekanan perifer dan peningkatan permeabilitas vaskuler yang menyebabkan hipoperfusi jaringan merupakan hal yang secara klinis sangat penting dalam pendekatan terapi sepsis. ${ }^{6}$ Gangguan fungsi jantung yang merupakan konsekuensi dari sepsis berat ditunjukkan dengan adanya gangguan kontraktilitas, gangguan fungsi diastolik, dan penurunan indeks jantung juga fraksi ejeksi. ${ }^{7}$ Pasien sepsis dengan gangguan fungsi sistolik maupun diastolik ataupun kombinasi dari keduanya memiliki angka mortalitas yang lebih tinggi dibandingkan pasien sepsis tanpa gangguan fungsi sistolik maupun diastolik. ${ }^{8}$ Gangguan fungsi jantung pada kasus sepsis merupakan gangguan yang reversibel, dan dengan terapi yang adekuat pada pasien untuk mengatasi sepsis dan infeksi yang menyebabkannya, fungsi jantung pasien dapat kembali.

Serum laktat merupakan marker yang menggambarkan kondisi hipoperfusi dan hipoksia global dari jaringan dan menjadi standar baku emas untuk menilai severity (tingkat keparahan) pada pasien sepsis. Kadar asam laktat pada pasien dengan sepsis ikut berpengaruh terhadap angka mortalitas pasien, terutama pada pasien dengan kadar asam laktat $>4 .{ }^{9}$

Nilai prognostik dari pengukuran kadar laktat awal dan setelah resusitasi telah dibuktikan dalam beberapa penelitian yang menyimpulkan bahwa penurunan kadar laktat setelah resusitasi yang adekuat terkait dengan hasil akhir yang lebih baik. Bukti-bukti eksperimental hingga saat ini menyarankan penurunan laktat minimum 10\% dalam sedikitnya 2 jam pertama resusitasi merupakan cara yang cukup baik untuk menilai respons resusitasi pada pasien sepsis. ${ }^{10}$

Pengukuran hemodinamik jantung dan total cairan tubuh merupakan komponen yang sangat penting untuk pembuatan keputusan terapi yang lebih baik pada pasien sepsis. Teknologi sejauh ini yang dapat secara objektif mengukur hemodinamik dan total cairan tubuh, seperti termodilusi menggunakan kateter arteri pulmoner Swan Ganz dan teknik bolus intermiten atau pulse contour analysis, belum dapat diintegrasikan pada setting gawat darurat karena invasif, memakan banyak waktu untuk menggunakan dan mengkalibrasinya, tidak dapat diandalkan, atau kombinasi dari alasanalasan tersebut. NiCAS (Non Invasive Cardiac System, NI Medical, Singapore) merupakan sebuah alat baru noninvasif untuk pengukuran parameter hemodinamik dan total cairan tubuh yang menggunakan teknik impedansi kardiograf. Sejumlah studi awal yang dilakukan telah menunjukkan korelasi yang bagus antara pengukuran hemodinamik menggunakan alat NiCAS dengan pengukuran termodilusi yang merupakan standar baku emas.

Peneliti ingin mengetahui ada tidaknya korelasi antara perbaikan parameter hemodinamik dan kadar cairan tubuh yang diukur 
dengan alat NiCAS dengan perbaikan kadar asam laktat dalam 2 jam pertama pada pasien-pasien sepsis dan syok sepsis di Instalasi Gawat Darurat RS. dr. Saiful Anwar Malang. Penelitian ini bertujuan untuk mencari metode noninvasif dan minim efek samping yang cukup objektif untuk memprediksi keberhasilan resusitasi pada pasien sepsis dan syok sepsis terutama pada jam-jam awal, sehingga dapat diguna-kan untuk membimbing tatalaksana serta manajemen pasien yang lebih tepat dan lebih baik.

\section{Bahan dan Metode}

Desain penelitian merupakan penelitian observasional analitik untuk mengkaji hubungan antara perubahan kadar asam laktat dengan perubahan variabel-variabel hemodinamik sebelum dan sesudah resusitasi serta kesesuaian alat NiCAS dalam mengevaluasi perbaikan kondisi pasien sepsis dan syok sepsis dibandingkan dengan asam laktat. Penelitian ini dilakukan di IGD RS. dr. Saiful Anwar pada bulan Desember 2017 sampai Desember 2018. Penelitian ini telah disetujui oleh Komisi Etik Penelitian Kesehatan RS. dr. Saiful Anwar malang dengan nomor: 400/02/K.3/302/2018.

Populasi penelitian adalah semua pasien sepsis dan syok sepsis yang datang ke IGD. Sampel yang diteliti merupakan semua pasien dengan kecurigaan sepsis dan syok sepsis berusia lebih dari 40 tahun yang dibawa ke IGD RSSA. Pasien hamil, pasien dengan riwayat tumor ganas dengan harapan hidup kurang dari 6 bulan, pasien rujukan dari fasilitas kesehatan lain yang sudah terpasang vasopressor, serta pasien dengan syok akibat perdarahan dieksklusi dari sampel. Semua pasien diperiksa kadar asam laktat dan NiCAS pada awal presentasi di IGD sebagai data awal dan dilakukan resusitasi sesuai dengan tatalaksana, kemudian dilakukan pemeriksaan kadar asam laktat dan NiCAS ulang pada saat 2 jam pasca resusitasi untuk evaluasi. Variabel yang diteliti adalah kadar asam laktat, total cairan tubuh (Total Body Water; TBW), resistensi perifer total (Total Peripheral Resistance; TPR), volume sekuncup (Stroke Volume; SV), keluaran jantung (Cardiac Output; CO), dan indeks jantung (Cardiac Index; Cl) yang diambil sebelum dan sesudah 2 jam resusitasi.

Analisis data dilakukan menggunakan software SPSS. Perubahan antara kadar asam laktat sebelum dan sesudah resusitasi serta hubungan antara indikator-indikator hemodinamik dan kadar cairan tubuh sebelum dan sesudah resusitasi diuji dengan paired t-test jika distribusi normal dan diuji dengan uji Wilcoxon jika distribusinya tidak normal.

Hubungan antara kadar asam laktat dengan masing-masing variabel independen dalam parameter hemodinamik serta total cairan tubuh yang diukur dengan menggunakan alat NiCAS diuji dengan uji korelasi Pearson, apabila distribusi tidak normal maka diuji dengan uji korelasi Spearman. Apabila hubungan masing-masing variabel didapatkan $p<0,25$ dapat dilanjutkan ke uji regresi linear dengan derajat kepercayaan $95 \%, a=$ 0,05 , bermakna bila $p<0,05$.

Kesesuaian antara perubahan kadar asam laktat dengan perubahan indikatorindikator hemodinamik dan total cairan tubuh setelah dua jam resusitasi disajikan dalam bentuk tabulasi dengan tabel $2 \times 2$, kemudian dilakukan analisis kesesuaiannya dengan uji McNemar.

Hasil

Ada 26 sampel yang dikumpulkan sejak Desember 2017 hingga Desember 2018. Kebanyakan pasien yang diduga sepsis atau syok sepsis adalah perempuan (17 orang; $65,4 \%$ ) dan berada pada kelompok usia 50 59 tahun dan lebih dari 70 tahun (8 orang; $30,8 \%$ ). Semua pasien memenuhi kriteria penapisan awal dengan qSOFA $\geq 2$, 
dengan 14 orang $(53,8 \%)$ memiliki nilai qSOFA sebesar 2 dan 12 orang $(46,2 \%)$ memiliki nilai qSOFA sebesar 3. Seluruh pasien juga memiliki nilai SOFA $\geq 2$. Data perbandingan asam laktat sebelum dan sesudah 2 jam resusitasi menunjukkan adanya perbedaan yang bermakna antara kadar laktat pre dan laktat pasca resusitasi ( $p$ $=0,002$ ).

Pada Tabel 2 ditampilkan hasil analisis perbedaan nilai indikator-indikator hemodinamik TPR (Total Peripheral Resistance; resistensi perifer total), SV (Stroke Volume; volume sekuncup), CO (Cardiac Output; keluaran jantung), dan $\mathrm{Cl}$ (Cardiac Index; indeks jantung) tidak terdapat perbedaan signifikan antara nilai awal datang dengan nilai 2 jam setelah resusitasi. Perbedaan signifikan hanya didapatkan pada nilai TBW (Total Body Water; total cairan tubuh) sebelum resusitasi dan 2 jam setelah resu- sitasi, dengan nilai $p=0,006$. Untuk menganalisis data korelasi perubahan kadar asam laktat dengan perubahan indikator-indikator hemodinamik dan kadar cairan tubuh setelah 2 jam resusitasi, digunakan uji korelasi Pearson karena data memenuhi uji linieritas dan berdistribusi normal (Tabel 3).

Dari hasil analisis (Tabel 3), didapatkan korelasi yang tidak signifikan antara $\Delta$ Laktat dengan $\triangle T P R$ dengan nilai $p=0,629$. Didapatkan korelasi yang tidak signifikan antara $\Delta$ Laktat dengan $\Delta$ SV dengan nilai $p=$ 0,46 . Untuk $\Delta$ Laktat dengan $\Delta C O$, juga didapatkan korelasi yang tidak signifikan dengan $p=0,487$. Perbandingan antara $\Delta$ Laktat dengan $\Delta \mathrm{Cl}$ menunjukkan korelasi yang juga tidak signifikan dengan nilai $p=$ 0,425 . Perbandingan antara $\Delta$ Laktat dengan $\triangle T B W$ juga menunjukkan korelasi yang tidak signifikan dengan nilai $p=0,831$.

Tabel 1. Karakteristik sampel

\begin{tabular}{lcc}
\hline \multicolumn{1}{c}{ Karakteristik } & Jumlah & $(\%)$ \\
\hline Jenis Kelamin & & \\
$\quad$ Laki - laki & 9 & 34,6 \\
$\quad$ Perempuan & 17 & 65,4 \\
Usia & & \\
$\quad 40-49$ & 4 & 15,3 \\
$50-59$ & 8 & 30,8 \\
$60-69$ & 6 & 23,1 \\
$\geq 70$ & 8 & 30,8 \\
Nilai qSOFA & & \\
2 & 14 & 53,8 \\
3 & 12 & 46,2 \\
Nilai SOFA* & & \\
$\quad 22$ & 26 & 100 \\
\hline Keterangan: & \\
*Quick Sepsis-related Organ Failure Assessment
\end{tabular}

Tabel 2. Analisis perbedaan kadar variabel sebelum dan sesudah 2 jam resusitasi dengan paired t-test

\begin{tabular}{lc}
\hline \multicolumn{1}{c}{ Variabel } & $p$ \\
\hline TPR sebelum - sesudah & 0,172 \\
SV sebelum - sesudah & 0,354 \\
CO sebelum - sesudah & 0,208 \\
Cl sebelum - sesudah & 0,210 \\
TBW sebelum - sesudah & 0,006 \\
\hline
\end{tabular}


Tabel 3. Korelasi variabel dengan uji Pearson

\begin{tabular}{lccc}
\hline \multicolumn{1}{c}{ Variabel } & $\mathrm{r}$ & $\mathrm{p}$ & $\mathrm{N}$ \\
\hline Delta Laktat - Delta TPR & .099 & .629 & 26 \\
Delta Laktat - Delta SV & -.150 & .465 & 26 \\
Delta Laktat - Delta CO & -.143 & .487 & 26 \\
Delta Laktat - Delta Cl & -.164 & .425 & 26 \\
Delta Laktat - Delta TBW & -.044 & .831 & 26 \\
\hline
\end{tabular}

Keterangan: TPR adalah total peripheral resistance; SV adalah stroke volume; CO adalah Cardiac Output; $\mathrm{Cl}$ adalah Cardiac Index; TBW adalah Total Body Water.

Tabel 4. Kesesuaian antar perubahan variabel dengan uji McNemar

\begin{tabular}{lccc}
\hline \multicolumn{1}{c}{ Variabel } & Kesesuaian $(\%)$ & $\mathrm{p}$ & $\mathrm{N}$ \\
\hline Delta Laktat - Delta TPR & 53.8 & .388 & 26 \\
Delta Laktat - Delta SV & 65.4 & .180 & 26 \\
Delta Laktat - Delta CO & 61.5 & .344 & 26 \\
Delta Laktat - Delta Cl & 61.5 & .754 & 26 \\
Delta Laktat - Delta TBW & 50 & .267 & 26 \\
\hline
\end{tabular}

Keterangan: TPR adalah total peripheral resistance; SV adalah stroke volume; CO adalah Cardiac Output; $\mathrm{Cl}$ adalah Cardiac Index; TBW adalah Total Body Water.

Selanjutnya, dilakukan analisis kesesuaian antara perubahan kadar asam laktat dengan perubahan variabel-variabel hemodinamik sebelum dan sesudah 2 jam resusitasi dengan menggunakan uji McNemar (Tabel 4). Dari hasil analisis, didapatkan kesesuaian antara perubahan asam laktat dengan perubahan TPR dengan $p=0,388$ pada $53,8 \%$ pasien. Untuk perubahan asam laktat dibandingkan dengan perubahan SV, didapatkan kesesuaian dengan $p=0,180$ pada $65,4 \%$ pasien. Perubahan kadar asam laktat dibandingkan dengan perubahan $\mathrm{CO}$, didapatkan kesesuaian dengan $p=0,344$ pada $61,5 \%$ pasien. Pada perbandingan antara perubahan kadar asam laktat dengan perubahan $\mathrm{Cl}$, didapatkan kesesuaian pada $61,5 \%$ pasien dengan $p=0,754$. Terakhir, analisis antara perubahan kadar asam laktat dengan perubahan TBW, didapatkan kesesuaian pada $50 \%$ pasien dengan $p=0,267$.

\section{Pembahasan}

Kegunaan perubahan kadar asam laktat sebagai indikator yang baik untuk menentukan keberhasilan resusitasi sudah dibuktikan dalam beberapa studi, bahwa penurunan kadar asam laktat minimal $10 \%$ dalam dua jam diasosiasikan dengan prognosis yang lebih baik, mortalitas yang lebih rendah, dan lama tinggal di ICU yang lebih singkat. .11-13

Pemberian cairan sebagai langkah awal resusitasi pada kasus sepsis ditujukan untuk mencegah cedera jaringan akibat hipoperfusi di jaringan dan organ-organ penting akibat turun-nya tekanan darah, sehingga memulai resusi-tasi cairan secara dini dapat mencegah perfusi yang rendah, dan kemudian mencegah per-burukan lebih lanjut dari iskemia organ akibat hipoksia. Sehingga akan membantu pemulihan yang lebih cepat dan memaksimalkan prognosis pasien. ${ }^{13}$ Pemberian cairan juga akan membantu perfusi ke jaringan-jaringan seperti ginjal dan hati, yang akan membantu meningkatkan klirens laktat. Pada tahap selanjutnya, jika pemberian cairan tidak dapat memaksimalkan tekanan darah, vasopressor dapat diberikan untuk membantu meningkatkan tekanan darah dan pencapaian perfusi organ. Jika resusitasi dilakukan dengan baik sesuai dengan sepsis bundle jam pertama, diharapkan terjadi perbaikan perfusi jaringan yang akan terlihat melalui penurunan kadar asam laktat yang adekuat. 
Pada penelitian ini, didapatkan perbedaan yang bermakna antara kadar laktat preresusitasi dan 2 jam pascaresusitasi $(p=$ 0,002). Hal ini menunjukkan keberhasilan pada tahap awal resusitasi 2 jam pertama yang dilakukan di IGD RS. dr. Saiful Anwar Malang, yaitu terjadi perbaikan pada pengiriman oksigen ke jaringan sehingga mengurangi metabolisme anaerobik, atau terjadi peningkatan klirens laktat seiring dengan perbaikan perfusi ke organ pembuangan seperti ginjal dan hati.

Dari data penelitian analisis perbedaan indikator-indikator hemodinamik serta kadar cairan tubuh (sebelum) dan indikator-indikator hemodinamik serta kadar cairan tubuh (sesudah) dengan menggunakan paired t-test didapatkan perbedaan yang signifikan pada kadar cairan tubuh (TBW) dengan nilai $p=$ 0,006 , sedangkan untuk variabel-variabel hemodinamik lain terdapat korelasi yang tidak signifikan.

Total cairan tubuh (TBW) terdiri dari cairan ekstraseluler dan cairan intraseluler. Pada pasien dengan sepsis dan syok sepsis, terjadi vasodilatasi dari pembuluh darah tubuh dan peningkatan permeabilitas dinding pembuluh darah. Dengan adanya teori baru tentang distribusi cairan resusitasi yaitu teori glycocalyx dan teori revised Starling, ${ }^{14}$ ditemukan bahwa ketika pasien diberikan cairan resusitasi, tidak semua cairan akan berada di intravaskular. Sebagian besar cairan akan berpindah ke interstitial dalam waktu cepat. Pada pasien sakit kritis dengan kerusakan endotelial dan kapiler yang rapuh, kurang dari $5 \%$ volume bolus cairan tetap berada di intravaskuler dalam 90 menit. 15

Berdasarkan panduan tatalaksana dari Surviving Sepsis Campaign 2012 untuk pasien sepsis dan syok sepsis, direkomendasikan resusitasi cairan secara agresif dalam 24 jam pertama penanganan dengan pemberian cairan awal bisa mencapai $30 \mathrm{~mL} /$ $\mathrm{kg}$, terutama pada kasus pasien syok sepsis. ${ }^{16}$ Dengan pemberian cairan resusitasi awal sesuai dengan tata-laksana, volume total cairan tubuh tentu akan ikut mengalami perubahan, walaupun tidak dapat diketahui distribusi cairan tersebut di antara kompartemen-kompartemen tubuh. Hal ini sesuai dengan hasil yang didapatkan peneliti, yaitu terjadi perubahan kadar cairan tubuh yang signifikan dengan pemeriksaan menggunakan alat NiCAS.

Resistensi perifer total pada pasien dengan sepsis dan syok sepsis mengalami penurunan yang disebabkan oleh vasodilatasi sistemik sebagai respons terhadap proses inflamasi. Vasodilatasi ini dapat terjadi sampai mengurangi resistensi perifer total menjadi hanya $25 \%$ dari nilai normalnya. Vaskularisasi dari pasien septik kemudian akan menjadi semakin tidak responsif bahkan terhadap agen-agen pressor simpatomimetik. ${ }^{17}$

Keseluruhan proses ini sangat bergantung pada kondisi masing-masing pasien, seperti ada tidaknya penyakit komorbid dan usia pasien. Oleh karena kompleksitas patofisiologinya, perjalanan penyakit pada kasus sepsis pun sulit untuk diprediksi. Pada penelitian ini, didapatkan perbedaan yang tidak signifikan antara TPR sebelum dan TPR sesudah 2 jam resusitasi. Ini kemungkinan disebabkan pada populasi pasien yang diteliti dalam penelitian ini, pasien datang pada waktu yang berbedabeda sejak permulaan penyakit. Sebagian pasien sudah jatuh pada kondisi syok. Pasien yang syok akan segera diterapi dengan vasopresor, sedangkan pasien yang belum jatuh dalam kondisi syok tidak langsung menerima vasopresor. Pada pasien yang menerima vasopressor, kemungkinan ada yang sudah jatuh dalam kondisi tidak responsif terhadap vasopresor. Kondisi preresusitasi yang berbeda-beda dan respons yang berbeda-beda terhadap cairan dan obat yang diberikan kemungkinan menyebabkan variasi yang cukup besar dan perbedaan yang tidak signifikan dengan kondisi pascaresusitasi 2 jam. 
Pada pasien sepsis, terjadi penurunan fungsi jantung yang disebabkan depresi miokard. Ini disebabkan oleh penekanan respons adrenergik di level kardiomiosit sebagai akibat dari down-regulation reseptor betaadrenergik. Perubahan ini dimediasi oleh banyak hal, seperti sitokin dan nitrit oksida. Mekanisme lain yang menyebabkan depresi otot jantung secara langsung pada sepsis adalah kerusakan atau kematian kardiomiosit, yang bisa dicetuskan oleh toksin, komplemen, DAMP, dan substansi depresan miokardial lain yang belum dapat diidentifikasi. ${ }^{18}$ Pada sepsis awal, dengan tekanan vaskuler sistemik yang rendah, gambaran $\mathrm{CO}$ masih dapat tampak normal ataupun meningkat, walaupun kenyataannya fungsi kontraktilitas jantung sudah tidak bagus. Walaupun SV masih dapat dipertahankan pada awalnya, akan didapatkan peningkatan left ventricular end-systolic volume (LVESV) dan left ventricular end-diastolic volume (LVEDV) dan penurunan ejeksi fraksi, dengan $\mathrm{CO}$ bertahan pada level normal dengan cara meningkatkan denyut jantung. ${ }^{19}$

Seiring perjalanan penyakit, respons kompensasi neuroendokrin akan terbebani secara berlebihan. Ini disebabkan oleh insensitivitas progresif dari sirkulasi perifer terhadap vasokonstriktor yang ada di sirkulasi, seperti vasopressin dan angiotensin II. Hal tersebut akan menyebabkan pasien sepsis jatuh ke kondisi syok sepsis, dan berangsur-angsur refrakter terhadap terapi. Pasien akan memiliki CO rendah, perfusi perifer buruk, ekstremitas dingin, dan akhirnya berujung pada kematian. Dengan resusitasi volume yang adekuat, walaupun terjadi penurunan signifikan resistensi vaskuler perifer, $\mathrm{Cl}$ pasien sepsis dapat ditemukan normal atau meningkat. Meskipun ditemukan $\mathrm{CO}$ yang meningkat dan SV yang normal, terdapat disfungsi miokard yang signifikan pada pasien dengan syok sepsis.

Pasien-pasien sepsis di rumah sakit memiliki karakteristik yang berbeda-beda, dengan usia, faktor komorbid, dan onset sepsis yang berbeda-beda pula. Pada penelitian ini, peneliti menemukan perbedaan yang tidak signifikan dari $\mathrm{CO}, \mathrm{SV}$, dan $\mathrm{Cl}$ pada pasien-pasien sepsis sebelum dan sesudah 2 jam resusitasi. Hal ini kemungkinan disebabkan pada saat presentasi pasien di IGD, pasien sudah berada dalam tahap-tahap yang berbeda dari perjalanan penyakitnya. Pasien yang memiliki faktor komorbid seperti penyakit jantung dan ginjal sebelumnya, kemungkinan juga akan lebih mudah jatuh ke kondisi depresi miokardial berat dan syok sepsis yang kurang responsif terhadap obat-obatan. Obat-obatan yang dikonsumsi harian oleh pasien juga kemungkinan akan mempengaruhi fungsi dasar dari jantung serta hemodinamik pasien, sehingga menyebabkan respons yang berbeda-beda setelah resusitasi.

Pada penelitian ini, didapatkan korelasi yang tidak signifikan antara perubahan kadar asam laktat dengan perubahan variabelvariabel hemodinamik pasien. Asidosis laktat pada sepsis seringkali dikaitkan dengan hipoksia jaringan ketika pengiriman oksigen di tubuh gagal memenuhi kebutuhan oksigen secara keseluruhan.

Sepsis juga menyebabkan gangguan pada kemampuan jaringan untuk mengekstrak oksigen. Selama sepsis terjadi, rasio ekstraksi oksigen berkurang hingga 50\% atau kurang, sehingga pembentukan asam laktat meningkat pada level oksigen yang biasanya cukup untuk memenuhi kebutuhan oksigen aerobik. Hipoksia jaringan ini kemudian akan mem-produksi laktat. Selain itu, disfungsi mitokondria juga terjadi, bahkan pada jaringan dengan oksi-genasi adekuat, metabolisme anaerobik tetap terjadi. Pada pasien sepsis dengan hemo-dinamik stabil, hiperlaktatemia dapat pula di-sebabkan oleh gangguan klirens dan bukannya produksi yang berlebihan. Penggunaan obat-obatan juga dapat mempengaruhi produksi laktat pada pasien sepsis. 
Misalnya, penggunaan adrenalin pada terapi pasien sepsis meningkatkan kadar laktat darah, tetapi menunjukkan angka survival yang lebih tinggi. Peningkatan kadar laktat pada kasus ini kemungkinan disebabkan oleh peningkatan glikolisis yang diinduksi oleh katekolamin. ${ }^{20}$

Pada kasus sepsis, peningkatan laktat tidak hanya menunjukkan hipoksia jaringan, tetapi dapat pula menunjukkan adanya respons adaptif terhadap proses metabolik dari infeksi berat dan dapat pula menunjukkan adanya respons terhadap terapi. ${ }^{21} \mathrm{Hal}$ ini menunjukkan bahwa kadar laktat tidak selalu berkorelasi dengan keparahan sepsis, apalagi jika pasien memiliki penyakit komorbid lain seperti gangguan liver dan ginjal atau mengkonsumsi obat-obatan seperti beta-bloker dalam kesehariannya, yang semuanya dapat mempengaruhi kadar asam laktat.

Pasien yang datang ke IGD RSSA dengan sepsis memiliki karakteristik yang berbeda, onset penyakit yang berbeda, komorbid penyakit yang berbeda, dan titik perjalanan penyakit yang berbeda pula. Sebagian mungkin sudah memiliki gangguan jantung atau liver atau ginjal sebelumnya, yang semua akan mempengaruhi indikator hemodinamik dasar pasien dan kemampuan tubuh pasien untuk memproduksi dan mengekskresi asam laktat dari tubuh. Obat-obatan yang dikonsumsi juga akan mempengaruhi kerja jantung dan kemu-dian indikator hemodinamik pasien. Banyaknya variasi pada pasien dan faktor yang dapat mempengaruhi kondisi pasien kemungkinan menyebabkan tidak adanya korelasi yang signifikan antara perubahan kadar asam laktat pasien dan perubahan indikator hemodinamik pasien.

Dari data penelitian analisis kesesuaian dengan uji McNemar, didapatkan nilai $p$ > 0,05 untuk kesesuaian antara perbaikan kadar asam laktat dengan perbaikan indikator -indikator hemodinamik (TBW, SV, CO, Cl, dan TPR) yang diukur dengan alat NiCAS, yang menunjukkan adanya kesesuaian antara variabel-variabel tersebut. Pengiriman oksigen ke jaringan dipengaruhi oleh SV, CO dan $\mathrm{Cl}$, sehingga perbaikan kadar asam laktat kira-kira dapat dipengaruhi oleh perbaikan kedua komponen hemodinamik tersebut. Pada tahap awal sepsis, pasien akan masuk di dalam fase ebb dimana terjadi hipovolemia intravaskuler absolut maupun relatif yang cukup berat. ${ }^{22}$ Pada fase ini, dengan rendahnya jumlah cairan tubuh, pengiriman oksigen ke jaringan pun akan terganggu. Jika dengan resusitasi adekuat pasien dapat dikembalikan ke dalam kondisi normovolemia, maka seiring dengan perbaikan jumlah total cairan tubuh, akan terjadi perbaikan pengiriman oksigen, dan perbaikan pula pada kadar asam laktat tubuh.

Akan tetapi, kesesuaian ini hanya didapatkan pada 50-65\% kasus saja. Ini kemungkinan disebabkan oleh kompleksitas dari patogenesis sepsis dan fase-fase perjalanan penyakit sepsis yang panjang, dengan berbagai kondisi pada fase-fase yang berbeda. Pada sepsis, setelah pasien mengalami fase $e b b$, pasien akan masuk pada fase flow, dimana pasien kemungkinan akan mengalami stase hipervolemik atau normovolemik dan mulai mengeluarkan cairan berlebih dari tubuh. Fase flow merupakan fase metabolik hiperkatabolik, dimana akan terjadi peningkatan konsumsi oksigen dan penggunaan energi, yang kemungkinan dapat meningkatkan kadar asam laktat darah. ${ }^{22}$

Perubahan indikator-indikator ini sulit diprediksi pengaruh ke depannya, karena dengan pasien yang berbeda, semakin banyak komorbid dan obat-obatan yang dikonsumsi pasien sebelumnya, akan sangat berbeda pula kemampuan sistem kardiovaskulernya untuk merespons obat-obatan dan tindakan resusitasi yang diberikan. Begitu pula dengan kinetik laktat, yang perubahannya tidak hanya dipengaruhi oleh fungsi hemodinamik dan kardiovaskuler pasien, tetapi juga dipengaruhi oleh kemampuan klirens laktat tubuh pasien, respons hipermetabolik 
pada fase akhir, adaptasi tubuh terhadap kondisi beta-adrenergik yang berlebihan sebagai respons pada sepsis, dan respon tubuh terhadap terapi yang diberikan. ${ }^{21}$ Sehingga, perbaikan pada indikator-indikator hemodinamik pasien tidak selalu menunjukkan perbaikan pula pada kadar asam laktat, dan begitu juga sebaliknya.

\section{Kesimpulan}

Kesimpulan yang diperoleh bahwa terdapat perubahan kadar asam laktat dan total cairan tubuh setelah dua jam resusitasi sesuai tatalaksana, tetapi perubahan ini tidak diikuti dengan perubahan variabel-variabel hemodinamik yang lain. Dapat dipertimbangkan pemberian cairan yang lebih minimal dan penggunaan vasopresor lebih dini. Korelasi antara perubahan kadar asam laktat dengan perubahan variabel-variabel hemodinamik juga tidak signifikan. Walaupun terdapat kesesuaian antara keduanya tetapi hanya didapatkan pada sebagian kasus, sehingga NiCAS belum bisa digunakan sebagai pengganti asam laktat dalam menilai perubahan kondisi pasien. Akan tetapi bisa dipertimbangkan sebagai alat bantu untuk memonitor kondisi pasien.

\section{Daftar Pustaka}

1. Deutschman CS, Tracey KJ. Sepsis: Current Dogma and New Perspectives. Immunity. 2014; 40(4):463-75.

2. Lyle $\mathrm{NH}$, Pena OM, Boyd JH, Hancock REW. Barriers to the Effective Treatment of Sepsis: Antimicrobial Agents, Sepsis Definitions, and host-Directed Therapies. Annals of the New York Academy of Sciences. 2014; 1323:101-14.

3. Singer M, Deutschman CS, Seymour CW, Shankar-Hari M, Annane D, Bauer M, et al. The Third International Consensus Definitions for Sepsis and Septic Shock (Sepsis-3). JAMA. 2016; 315(8):801-10.
4. Seymour C, Liu V, Iwashyna $T$, Brunkhorst $F$, Rea $T$, Scherag A, et al. Assessment of Clinical Criteria for Sepsis: For the Third International Consensus Definitions for Sepsis and Septic Shock (Sepsis-3). JAMA. 2016; 315(8):762.

5. Noersjahdu H. Laporan Evaluasi Hasil Kegiatan Pelayanan RSUD Dr. Saiful Anwar Triwulan III Tahun 2015. In: Keperawatan PM (Editor). RSUD Dr. Saiful Anwar Malang: Bidang Rekam Medik \& Evaluasi Pelaporan. 2015.

6. Drosatos K, Lymperopoulos A, Kennel PJ, Pollak N, Schulze PC, Goldberg IJ. Pathophysiology of Sepsis-Related Cardiac Dysfunction: Driven by Inflammation, Energy Mismanagement, or Both? Curr Heart Fail Rep. 2015; 12 (2):130-40.

7. Zaky A, Deem S, Bendjelid K, Treggiari MM. Characterization of Cardiac Dysfunction in Sepsis: an Ongoing Challenge. Shock. 2014; 41(1):12-24.

8. Landesberg G, Gilon D, Meroz Y, Georgieva M, Levin PD, Goodman S, et al. Diastolic Dysfunction and Mortality in Severe Sepsis and Septic Shock. Eur Heart J. 2012; 33(7):895-903.

9. Berger $T$, Green J, Horeczko $T$, Hagar $Y$, Garg N, Suarez A, et al. Shock Index and Early Recognition of Sepsis in the Emergency Department: Pilot Study. Western Journal of Emergency Medicine. 2013; XIV:168-74.

10. Jones $A E$. Lactate Clearance for Assessing Response to Resuscitation in Severe Sepsis. Acad Emerg Med. 2013; 20(8):844-7.

11. Jones AE, Shapiro NI, Trzeciak S, Arnold $\mathrm{RC}$, Claremont HA, Kline JA, et al. Lactate Clearance vs Central Venous Oxygen Saturation as Goals of Early Sepsis Therapy: a Randomized Clinical Trial. JAMA. 2010; 303(8):739-46. 
12. Jansen TC, van Bommel J, Schoonderbeek FJ, Sleeswijk Visser SJ, van der Klooster JM, Lima AP, et al. Early Lactate-Guided Therapy in Intensive Care Unit Patients: a Multicenter, Open-Label, Randomized Controlled Trial. Am J Respir Crit Care Med. 2010; 182(6):75261.

13. Pan J, Peng M, Liao C, Hu X, Wang A, Li $X$. Relative Efficacy and Safety of Early Lactate Clearance-Guided Therapy Resuscitation in Patients with Sepsis: A Meta-Analysis. Medicine. 2019; 98(8).

14. Woodcock T, Woodcock TM. Revised Starling Equation and the Glycocalyx Model of Transvascular Fluid Exchange: an Improved Paradigm for Prescribing Intravenous Fluid Therapy. British Journal of Anaesthesia. 2012; 108(3):384-94.

15. Malbrain ML, Marik PE, Witters I, Cordemans C, Kirkpatrick AW, Roberts DJ, et al. Fluid Overload, deResuscitation, and Outcomes in Critically III or Injured Patients: a Systematic Review with Suggestions for Clinical Practice. Anaesthesiology Intensive Therapy. 2014; 46(5):361-80.

16. Dellinger RP, Levy MM, Rhodes A, Annane D, Gerlach H, Opal SM, et al. Surviving Sepsis Campaign: International Guidelines for Management of Severe
Sepsis and Septic Shock, 2012. Intensive Care Medicine. 2013; 39(2):165-228.

17. Young JD. The Heart and Circulation in Severe Sepsis. British Journal of Anaesthesia. 2004; 93(1):114-20.

18. Kakihana $Y$, Ito $T$, Nakahara $M$, Yamaguchi K, Yasuda T. Sepsis-Induced Myocardial Dysfunction: Pathophysiology and Management. J Intensive Care. 2016; 4:22.

19. Greer J. Pathophysiology of Cardiovascular Dysfunction in Sepsis. BJA Education. 2015;15(6):316-21.

20. Omar S, Burchard A, Lundgren A, Mathivha L, Dulhunty J. The Relationship between Blood Lactate and Survival Following the Use of Adrenaline in the Treatment of Septic Shock. Anaesthesia and Intensive Care. 2011;39(3):449-55.

21. Suetrong $B$, Walley KR. Lactic Acidosis in Sepsis: It's Not All Anaerobic: Implications for Diagnosis and Management. Chest. 2016; 149(1):25261.

22. Malbrain ML, Van Regenmortel N, Saugel B, De Tavernier B, Van Gaal P-J, Joannes-Boyau $O$, et al. Principles of Fluid Management and Stewardship in Septic Shock: It Is Time to Consider the Four D's and the Four Phases of Fluid Therapy. Annals of intensive care. 2018; 8(1):66. 